\title{
Effect of Lactobacillus casei and Lactobacillus acidophilus in Laying Hens Challenged by Escherichia coli Infection
}

(Kesan Lactobacillus casei dan Lactobacillus acidophilus dalam Ayam Bertelur yang Dijangkiti Escherichia coli)

\author{
WIDYA PARAMITA LOKAPIRNASARI*, AdRIANA MONICA SAHIDU, LILIK MASLACHAH, EMy KoESTANTI \\ SABDONINGRUM \& ANDREAS BERNY YULIANTO
}

\begin{abstract}
This study aimed to prove the potential of Lactobacillus casei and Lactobacillus acidophilus probiotics as alternative substitutes of antibiotic growth promoters in laying hens challenged by Escherichia coli infection in order to enhance their growth performance and hen day production. The study used a total of 120 laying hens aged 25 weeks, divided into $3 \times 2$ treatments with each comprising 4 replications, and each replication consisted of 5 hens. The study used a completely randomised factorial design; factor a was the feed additive (control, antibiotics growth promoters /AGP, probiotic), whereas factor $b$ was the E. coli infection (non-infection and E. coli infection). The results showed that there were significant differences $(p<0.05)$ between the treatment of feed additive (factor $a)$, and $\mathrm{E}$. coli infection (factor $b$ ), and interaction $(p<0.05)$ between the feed and the infection for the egg weight, hen day production, feed conversion ratio and feed efficiency. The probiotic use of $0.5 \% \mathrm{~L}$. casei $+0.5 \% \mathrm{~L}$. acidophilus in hens either infected or uninfected with E. coli still produced the highest egg weight, hen day production, feed efficiency and reduced feed conversion ratio compared to all treatments. Based on the results, it can be concluded that the use of probiotics $0.5 \% \mathrm{~L}$. casei and $0.5 \% \mathrm{~L}$. acidophilus act as alternative substitutes for antibiotic growth promoters in laying hens challenged by $\mathrm{E}$. coli infection.
\end{abstract}

Keywords: E. coli; growth performance; hen day production; Lactobacillus acidophilus; Lactobacillus casei

ABSTRAK

Kajian ini bertujuan membuktikan potensi probiotik Lactobacillus casei dan Lactobacillus acidophilus sebagai pengganti alternatif penggalak pertumbuhan antibiotik (AGP) dalam ayam bertelur yang dijangkiti Escherichia coli terhadap prestasi pertumbuhan dan pengeluaran telur harian. Kajian ini menggunakan 120 ekor ayam bertelur berumur 25 minggu yang dibahagikan kepada rawatan $3 \times 2$, dengan setiap rawatan terdiri daripada 4 replikasi dan setiap replikasi terdiri daripada 5 ekor ayam bertelur. Kajian ini menggunakan reka bentuk faktoran rawak lengkap; faktor a adalah makanan tambahan (kawalan, AGP, probiotik), manakala faktor $b$ adalah faktor jangkitan E. coli (bukan jangkitan dan jangkitan E. coli). Hasil kajian menunjukkan terdapat perbezaan yang signifikan $(p<0.05)$ antara rawatan aditif makanan (faktor a) dan rawatan jangkitan E. coli (faktor b), serta interaksi antara faktor makanan tambahan dan jangkitan pada berat telur, pengeluaran telur harian, nisbah penukaran makanan dan kecekapan suapan. Penggunaan probiotik $0.5 \%$ L. casei $+0.5 \%$ L. acidophilus dalam ayam sama ada dijangkiti atau tidak dijangkiti E. coli masih memberikan berat telur tertinggi, pengeluaran telur harian dan kecekapan suapan yang tertinggi dan menurunkan nisbah penukaran makanan berbanding semua rawatan. Berdasarkan hasil kajian, dapat disimpulkan bahawa penggunaan probiotik $0.5 \% \mathrm{~L}$. casei $+0.5 \% \mathrm{~L}$. acidophilus dapat digunakan sebagai pengganti alternatif bagi promoter pertumbuhan antibiotik dalam ayam petelur yang dijangkiti E. coli.

Kata kunci: E. coli; Lactobacillus acidophilus; Lactobacillus casei; pengeluaran telur harian; prestasi pertumbuhan

\section{INTRODUCTION}

Avian Pathogenic Escherichia coli (APEC) is an extra intestinal bacterium responsible for poultry colibacillosis. It affects chicken of all age groups leading to an increase in morbidity and mortality rate. In hens and broilers, pathogenic $E$. coli could generate numerous systemic infections that can cause pericarditis, perihepatitis, salpingitis, salpingoperitonitis, colisepticaemia and airsacculitis infections, thereby, leading to decreases in egg production and economic losses (Dou et al. 2016; Paixao et al. 2016; Paudel et al. 2016). There are two forms of colibacillosis in laying hens, the salpingitis/ peritonitis/salpingoperitonitis (SPS) and the E. coli peritonitis syndrome (EPS) (Landman \& van Eck 2017). 
The pathogenic and commensal E. coli strains colonise the mammalian intestine by interacting metabolically and physically with other microbiota in the mucus layer of the cecal and colonic epithelium (Mokszycki et al. 2018). The stressor factor faced is the level of acidity in the stomach and its ability to survive in these conditions, owing to its stationary phase. In this condition, the bacteria are able to impede the system resistance or protection against acidity (Conway \& Cohen 2015; Foster 2004) and after reaching the colon, they use nutrients to exit lag phase and grow. The failure in transition from the lag to logarithmic phase leads to the elimination of E. coli bacteria (Conway \& Cohen 2015).

The use of unsuitable antibiotic growth promoters (AGP) in poultry farming induces bacteria resistant to antibiotics leading to the accumulation of antibiotic residues in the poultry products. This poses a threat to those consuming these poultry products, hence, many countries have prohibited to use them in poultry farms. Probiotics are considered as natural feed additives which can have a positive effect similar to AGP. Its supplementation in poultry feed has been reported to enhance growth performance (Awad et al. 2009; Tang et al. 2017). nutritional retention and caecal microbial balance (Mookiah et al. 2014; Mountzouris et al. 2010).

Probiotics are classified as the zootechnical feed additives and can be in the form of enzymes or microorganisms. They are non-pathogenic living microbes capable of improving the health of its host by increasing the microbial balance in intestine (Anadón 2006; Fuller 2001). The probiotic lowers the risk of gastro-intestinal diseases by stimulating the growth of beneficial microbes, improve immune modulatory, modulate the activity of epithelial cells, dendritic cells, natural killers, and the enhancement of nutrients bioavailability (Chiang \& Pan 2012; Untoo et al. 2018; Yahfoufi et al. 2018). Probiotics could protect host against pathogens by colonisation in the gastrointestinal tract (Getachew 2016). Probiotics can be used as an alternative substitute for antibiotic growth promoters, owing to its beneficial effect on the health of its host in chicken's productivity, serum lipids and the intestinal morphology (Khaksefidi \& Ghoorchi 2006; Nayebpor et al. 2007; Willis et al. 2007). The probiotic functions in disease prevention can be through competitively excluding gut pathogens, modulating gastrointestinal immune responses and producing metabolites such as bacteriocins that inhibit or kill pathogenic bacteria. For supporting growth performance, probiotics can counteract dysbiosis, maintain and replenish normal microorganism balance, and contribute in optimising nutrient absorption (Park et al. 2016).

There is still a limited number of research that has been conducted on the use of probiotics with the combination of $L$. casei and L. acidophilus in laying hens. The aim of this study was to determine the potential of L. casei and L. acidophilus probiotic as an alternative substitute of antibiotic growth promoters in laying hens challenged by $E$. coli infection on egg weight, hen day production, feed conversion ratio and feed efficiency.

\section{MATERIALS AND METHODS}

\section{ETHICAL APPROVAL}

An approval from the Faculty of Veterinary Medicine Universitas Airlangga was obtained before the experimental trial, No: 1.KE.166.09.2018. The isolates were obtained from collections belonging to Widya Paramita Lokapirnasari, Animal Husbandry Department, Faculty of Veterinary Medicine, Universitas Airlangga. The source of laying hens (ISA 2019) was from commercial farm.

\section{EXPERIMENTAL DESIGN}

The experimental design used was a factorial Completely Randomised Design (CRD). In the first factor, feed additives, consisted of 3 subfactors namely control, AGP and probiotic were utilised, while the second factor (E. coli infection), consisted of 2 subfactors namely the control treatment for hens not infected with $E$. coli and those infected. The isolates were obtained from the collection belonging to Emy Koestanti Sabdoningrum, Animal Husbandry Department, Faculty of Veterinary Medicine, Universitas Airlangga). The isolates $L$. casei and L. acidophilus were obtained from collections belonging to Widya Paramita Lokapirnasari, Animal Husbandry Department, Faculty of Veterinary Medicine, Universitas Airlangga (Yulianto \& Lokapirnasari 2018).

\section{LAYERS AND HOUSING}

ISA Brown laying hens (120) aged 25 weeks' old obtained from a commercial farm were used. They were randomly divided into $3 \times 2$ groups, with each group consisted of 4 replications and 5 layer chickens and placed in individual battery cages with a size of $20 \times 35 \times$ $35 \mathrm{~cm}$ with ad libitum drinking water and feeding. The climatic conditions and lighting programs were operated following the recommendations of Institut de Sélection Animale BV of ISA Brown throughout the experiment (ISA 2019).

\section{FEED, PROBIOTIC AND E. COLI TREATMENTS}

The feed was given twice a day as much as $150 \mathrm{~g} / \mathrm{hen} /$ day. Laying hens were fed a commercial layer diet with the following specifications: dry matter: $91.97 \%$, ash: $9.28 \%$, crude protein: $20.71 \%$, extract ether $6.36 \%$, crude fiber: $7.43 \%$; nitrogen free extract (NFE): $48.18 \%$ and energy metabolism (EM:2938.60 Mcal $/ \mathrm{kg}$ ). Drinking water was given ad libitum during the treatment.

The induced $E$. coli bacteria containing $1 \times 10^{8} \mathrm{CFU} /$ $\mathrm{mL} E$. coli was given orally through a disposable sterile syringe at $10^{8} \mathrm{CFU} / \mathrm{mL} /$ hen to 28 weeks' old laying hens. Then, the clinical symptoms such as diarrhoea and decreased feed intake were observed. 
The AGP treatment at $0.01 \%$ of feed was given every day for 4 weeks to laying hens at 26 to 30 weeks old. The probiotic administration contained $0.5 \% \mathrm{~L}$. casei and $0.5 \%$ L. acidophilus at $4.77 \times 10^{8} \mathrm{CFU} / \mathrm{mL}$ was given orally through drinking water. The probiotic administration was given for 4 weeks starting from 26 to 30 weeks old. Production performance data were carried out starting from the treatment of $E$. coli induction till the end of the study ( 28 to 30 weeks old). The egg weight, hen day production, Feed Conversion Ratio (FCR) and feed efficiency were obtained to analyse growth performance. For egg weight, the eggs were collected daily and the weight was recorded to calculate the mean egg weight using an electronic digital balance. FCR was calculated by dividing the feed intake by egg production. Feed intake was determined by subtracting the remaining feed from the original amount of feed at the end of each week. Feed efficiency (\%) was calculated by dividing the egg production by feed intake and multiplying by 100 . Hen day production was calculated by dividing number of eggs per day by number of laying hens per day and multiplying by 100 (Lokapirnasari et al. 2019a; Rattanawut et al. 2018). Eggs were extracted from 120 hens $(3 \times 2$ treatments, 4 replications and each replication consisted of 5 laying hens) and weighed daily from the $26^{\text {th }}$ to $30^{\text {th }}$ week. The treatments used were as follow:

Control treatment (T0): negative control (not treated with AGP or probiotics and chicken not infected with E. coli); Treatment 1 (T1): $0.1 \%$ AGP and chicken not infected with E. coli; Treatment 2 (T2): $0.5 \%$ L. casei and $0.5 \%$ L. acidophilus and chicken not infected with E. coli; Treatment 3 (T3): positive control (not given antibiotics or probiotics and chicken infected with $E$. coli); Treatment 4 (T4): $0.1 \%$ AGP and chicken infected with E. coli; and Treatment 5 (T5): $0.5 \%$ probiotics $L$. casei and $0.5 \%$ L. acidophilus and chicken infected with E. coli.

\section{STATISTICAL ANALYSIS}

Data of egg weight, hen day production, FCR and feed efficiency were compared between treatment groups using univariate general linear model statistics. If the results obtained were significantly different $(\mathrm{p}<0.05)$, it would be followed by subsequent Duncan multiple range tests.

\section{RESULTS AND DISCUSSION}

\section{EGG WEIGHT}

The results of the statistical analysis showed significant differences $(p<0.05)$ between treatment factors a (feed additives) with the use of additive feeds on the egg weight. The treatment of factor $\mathrm{b}$ (E. coli infection) also showed significant differences $(p<0.05)$ between the infected chicken and $E$. coli infection against egg weight. Between factors $a$ and $b$, there was an interaction $(p<0.05)$ on the additive feed on the egg weight (Table 1).

TABLE 1. Average egg weight for different treatments

\begin{tabular}{cccc}
\hline Factor a $\times$ factor b & $\begin{array}{c}\text { Control without feed additive } \\
(\mathrm{b} 0)\end{array}$ & $0.1 \%$ AGP (b1) & Probiotic (b2) \\
\hline Non infected (a0) & $58.500^{\mathrm{b}} \pm 0.01$ & $58.900^{\mathrm{c}} \pm 0.01$ & $61.225^{\mathrm{e}} \pm 0.09$ \\
& $58.300^{\mathrm{a}} \pm 0.01$ & $58.300^{\mathrm{a}} \pm 0.01$ & $60.925^{\mathrm{d}} \pm 0.09$ \\
Infected (a1) &
\end{tabular}

The lowest egg weight was produced in the control treatment i.e. without AGP administration and probiotics in $E$. coli infected chickens. No difference was noted with the treatment of AGP in E. coli-infected laying hens. The highest egg weight was found in the treatment of probiotics L. casei, and L. acidophilus in laying hens not infected with $E$ coli with the value of 61.225 (g/egg). The size of the eggs produced were in the range of 58.30 to 61.225 g. This result was supported by other studies in which the probiotic containing L. casei, and L. rhamnosus at 1.2 $\times 10^{8} \mathrm{CFU} / \mathrm{g}$ could increase the egg weight, egg length and egg width of quail eggs (Lokapirnasari et al. 2019b).
Similarly, the weight of chicken eggs treated with the probiotics, L. casei, and L. acidophilus in this research gave higher results than Tang et al. (2017), where the use of probiotic increased the egg weight in laying hens to $55.07 \mathrm{~g}$ compared to control $(37.68 \mathrm{~g})$ with medium size at 20 to 36 weeks. The size distribution of small (42.50 to $49.59 \mathrm{~g}$ ), medium (49.60- to $6.69 \mathrm{~g}$ ), large (56.70 to $63.78 \mathrm{~g}$ ), extra large (63.79 to $70.87 \mathrm{~g}$ ) and jumbo size eggs ( $>70.88 \mathrm{~g}$ ) was determined based on specified weights according to the United States Department of Agriculture (USDA) (Tang et al. 2017). It was shown that the administration of probiotics, L. casei, and $L$. 
acidophilus, gave favourable results as they did not lead to a decrease in egg weight despite the fact that the chicken was infected with $E$. coli.

\section{HEN DAY PRODUCTION}

The Hen Day Production (HDP) is a comparison of the number of eggs produced with the number of laying hens multiplied by $100 \%$. The statistical analysis results showed significant differences $(p<0.05)$ between treatment factors a using HDP feed additives. The treatment of factor $b$ also showed significant differences $(\mathrm{p}<0.05)$ between the infected chicken and $E$. coli infection against HDP (Table 2).

TABLE 2. Average hen day production (HDP) for different treatments

\begin{tabular}{|c|c|c|c|}
\hline Factor $\mathrm{a} \times$ factor $\mathrm{b}$ & Control without feed additive (b0) & $0.1 \%$ AGP (b1) & Probiotic (b2) \\
\hline Non infected (a0) & $94.700^{d} \pm 0.05$ & $93.300^{\mathrm{c}} \pm 0.05$ & $97.000^{\mathrm{e}} \pm 1.288$ \\
\hline Infected (a1) & $69.300^{\mathrm{a}} \pm 0.05$ & $89.300^{\mathrm{b}} \pm 0.05$ & $96.000^{\mathrm{e}} \pm 1.061$ \\
\hline
\end{tabular}

E. coli infection. The lowest HDP results were found in the positive control treatment, i.e. without AGP or probiotics and $E$. coli infection which was $69.3 \%$. The egg production in chicken treated with AGP and E. coli infection was higher $(89.3 \%)$ than the others. This indicated that hens not treated with AGP and E. coli infection tended to show a decrease in egg production. Previous study had shown that the use of probiotics resulted in an increase of egg production at $76.51 \%$ compared to control $(69.29 \%)$ (Tang et al. 2017). The HDP obtained as an effect of the use of probiotics, L. casei and L. acidophilus, showed a higher result. The highest HDP was found in the treatment of probiotics, $L$. casei and L. acidophilus, in laying hens not infected with $E$. coli $(97.00 \%)$ and not significantly different from the treatment of probiotics in $E$. coli infected chicken $(96.00 \%)$. The results indicated that when the probiotics were given to laying hens, no decrease in HDP was observed even though the chicken were infected with $E$. coli. The treatment of AGP in $E$. coli-infected laying hens showed a decrease in HDP of $4.28 \%$ compared to non-infected laying hens. In a positive control treatment where there was no addition of AGP or probiotics and the presence of $E$. coli infection, a decrease in HDP by $26.82 \%$ was observed compared to those not infected with E. coli. E. coli infection reduces the percentage of egg production (Landman \& van Eck 2017), but the use of probiotics, $L$. casei and L. acidophilus, were able to inhibit pathogenic E. coli hence not affecting the decrease in the host health since the probiotic strains inhibit the growth and colonisation of other pathogenic microorganisms (Shokryazdan et al. 2014). Lactic acid produced by Lactobacillus causes the environment to become acidic compared to its ability to inhibit the growth of pathogenic bacteria (Bernardeau et al. 2008). This result was in line with Raka et al. (2014) who reported that supplementing Liquid Probiotics Mixed Culture (LPMC) with Lactobacillus and Bacillus species showed the highest egg weight and hen day production in layers' chicken.

\section{FEED CONVERSION RATIO}

Feed Conversion Ratio (FCR) is the ratio between the amounts of feed consumed and the weight of the eggs produced. The statistical analysis results showed significant differences $(\mathrm{p}<0.05)$ between the treatment in factors a, using additive feeds on the FCR. The treatment of factor $\mathrm{b}$ also showed significant differences $(\mathrm{p}<0.05)$ between infected chicken and $E$. coli infection against FCR, with an interaction $(p<0.05)$ between the factors of infection and the factor feed additive (Table 3 ).

TABLE 3. Average of feed conversion ratio (FCR) for different treatments

\begin{tabular}{cccc}
\hline Factor $\mathrm{a} \times$ factor $\mathrm{b}$ & Control without feed additive (b0) & $0.1 \%$ AGP (b1) & Probiotic (b2) \\
\hline Non infected (a0) & $2.100^{\mathrm{c}} \pm 0.001$ & $2.100^{\mathrm{c}} \pm 0.001$ & $1.925^{\mathrm{a}} \pm 0.05$ \\
Infected (a1) & $2.900^{\mathrm{e}} \pm 0.001$ & $2.200^{\mathrm{d}} \pm 0.001$ & $1.975^{\mathrm{b}} \pm 0.05$ \\
\hline $\mathrm{a}, \mathrm{b}, \mathrm{c}, \mathrm{d}, \mathrm{e}$. & The different superscripts showed the significant differences $(\mathrm{p}<0.05)$ among the treatments
\end{tabular}


The best feed conversion ratio value was found in the treatment of probiotics, L. casei and L. acidophilus, in $E$. coli infected chicken. The highest FCR value was produced in the control treatment, i.e in hens not given AGP or probiotics and infected with E. coli. The result was found to be 2.900 , followed by the treatment of E. coli-infected hens using AGP, which amounted to 2.200. The outcome indicated that the administration of probiotics, L. casei and L. acidophilus, in hens provided a good feed conversion value compared to AGP, therefore, the probiotics helped in increasing feed consumption, owing to the enhanced digestibility of feed in the digestive tract of the livestocks. The enhanced feed consumption has an impact on growth and improves the feed conversion ratio (Bidarkar et al. 2014). The positive effect of $L$. casei and L. acidophilus probiotics in feed conversion ratio and feed efficiency might be due to the ability of the probiotics to induce physical changes in the gut structure, particularly in the development of crypt depth ratio and villus height in the ileum (Awad et al. 2008), thus increasing nutrient digestibility (Park et al. 2016).

The administration of $L$. casei and L. acidophilus probiotics to hens treated with $E$. coli infection, gave the best FCR value which was 1.925 . This is because chickens in healthy conditions do not consume much feed and produce highest number of eggs. It also showed a better FCR value (1.975) than the use of AGP in non-infected and infected hens (2.100) and (2.200), respectively. The FCR value of negative control and the use of AGP gave an FCR value of 2.100. The highest FCR value was produced in the positive control treatment, i.e. in hens not given AGP or probiotics but infected with $E$. coli which increased to 2.900 . The results of the study done by Tang et al. (2017) showed that the use of probiotics improved FCR results (2.32) compared to controls (2.55). Probiotics can help maintain the health of the digestive tract by providing beneficial microbial balance. A healthy and functioning digestive and intestinal tract can reduce digestive disorders resulting in better nutrient utilisation and feed conversion to produce increased growth and productivity (Fuller 2001). The previous results were in agreement with the present experiment (Table 3), that the reduction in FCR by probiotic supplementation related to its promoting positive effects on metabolic processes of nutrient digestion and nutrients utilisation and increasing the host health status. The probiotic supplementation could enrich the diversity of Lactobacillus spp. in jejunum and cecum by increasing the abundance and prevalence of Lactobacillus spp. inhabiting the intestine, maintaining the natural stability of indigenous microbial and restoring the microbial flora balance (Hayirli et al. 2005).

\section{FEED EFFICIENCY}

The statistical analysis showed that there were differences between the feed additive factors $(\mathrm{p}<0.05)$ on the feed efficiency. The same results were also shown in the infection factors $(p<0.05)$ with the factorial test analysis indicating an interaction between the feed additive and the infection for feed efficiency (Table 4).

TABLE 4. Average feed efficiency for different treatments

\begin{tabular}{|c|c|c|c|}
\hline Factor $\mathrm{a} \times$ factor $\mathrm{b}$ & Control without feed additive (b0) & $0.1 \%$ AGP (b1) & Probiotic (b2) \\
\hline Non infected (a0) & $51.3800^{\mathrm{b}} \pm 0.001$ & $51.7600^{\mathrm{c}} \pm 0.001$ & $53.8700^{\mathrm{e}} \pm 0.133$ \\
\hline Infected (a1) & $51.1400^{\mathrm{a}} \pm 0.001$ & $51.2800^{\mathrm{b}} \pm 0.001$ & $53.1975^{\mathrm{d}} \pm 0.101$ \\
\hline
\end{tabular}

The use of L. casei and L. acidophilus probiotics was able to inhibit colonisation of $E$. coli to compete in obtaining the nutrients needed. This was supported by several studies where the success of $E$. coli colonisation depends on competition with other micro biota (Khaksefidi \& Ghoorchi 2006), penetration of the mucus layer (Møller et al. 2003), and its ability to avoid host defenses (Bergstrom et al. 2012; McGuckin et al. 2011). The use of probiotic strains helps to maintain microbial balance in gastrointestinal tract and make changes in the composition of the intestinal micro flora by increasing beneficial bacteria and suppressing harmful pathogenic bacteria like E. coli (Fuller 2001; Srinu et al. 2013). This is due to the existence of competitive exclusion to compete for nutrition and attachment to the intestinal epithelial wall, or the ability of probiotic strains to produce antimicrobial substances or synergism between the two mechanisms (Mountzouris et al. 2010; Sohail et al. 2011). Other study also reported that probiotics have good effects in improving digestion, absorption and nutrient availability (Endens 2003). The use of probiotics containing Lactobacilli, Bifidobacterium thermophilum and Enterococcus faecium increases the jejunal villus height (Chichlowski et al. 2007), that it can 
increase nutrient absorption and be used for growth and production. The supplementation of $L$. sporogenes at 100 $\mathrm{mg} / \mathrm{kg}$ diet $\left(6 \times 10^{8}\right.$ spores $)$ significantly increased the egg production and feed efficiency (Panda et al. 2008).

The effect of both antibiotics and probiotics on animals seem to be similar. In this study, the effect of giving AGP and probiotics containing $L$. casei and $L$. acidophilus showed the beneficial effect in decreasing FCR, and increasing feed efficiency, hen day production and egg weight. The positive impact of giving antibiotics on laying hens are related to changes of the microbial community in the gastrointestinal tract both in the ileum and the caecum (Choi et al. 2018) especially toward short-chain fatty acid producers (Banerjee et al. 2018), but also to the increase of amino acid metabolites, fatty acids, nucleosides, and vitamins (Gadde et al. 2018). Antibiotics could improve performance of chicken through an anti- inflammatory effect mediated by the intestinal epithelium (Niewold 2007).

\section{CONCLUSION}

The use of probiotics, $0.5 \%$ L. casei and $0.5 \% \mathrm{~L}$. acidophilus, can be used as alternative substitutes for antibiotic growth promoters. They can provide better results for the laying hens performance to increase egg production (egg weight, hen day production, feed conversion ratio and feed efficiency) compared to the control and use of AGP, in both infected and uninfected laying chickens with E. coli. The use of L. casei and L. acidophilus probiotics would avoid the use of antibiotics in poultry industry.

\section{ACKNOWLEDGEMENTS}

The research team is grateful to the Ministry of Research and Technology of Higher Education (Kemenristekdikti), Chair of the Research and Innovation Institute, Rector Universitas Airlangga for funding this research (PTUPT 2019).

\section{REFERENCES}

Anadón, A. 2006. WS14 The EU ban of antibiotics as feed additives alternatives and consumer safety. Veterinary Pharmacology and Therapeutics 29: 41-44.

Awad, W., Ghareeb, K. \& Böhm, J. 2008. Intestinal structure and function of broiler chickens on diets supplemented with a synbiotic containing Enterococcus faecium and oligosaccharides. International Journal of Molecular Sciences 9(11): 2205-2216.

Awad, W.A., Ghareeb, K., Abdel-Raheem, S. \& Böhm, J. 2009. Effects of dietary inclusion of probiotic and synbiotic on growth performance, organ weights, and intestinal histomorphology of broiler chickens. Poultry Science 88(1): 49-56.

Banerjee, S., Sar, A., Misra, A., Pal, S., Chakraborty, A. \& Dam, B. 2018. Increased productivity in poultry birds by sub-lethal dose of antibiotics is arbitrated by selective enrichment of gut microbiota, particularly short chain fatty acid producers. Microbiology 164(2): 142-153.

Bergstrom, K.S., Sham, H.P., Zarepour, M. \& Vallance, B.A. 2012. Innate host responses to enteric bacterial pathogens: A balancing act between resistance and tolerance. Cellular Microbiology 14(4): 475-484.

Bernardeau, M., Vernoux, J.P., Dubernet, S.H. \& Guéguen M. 2008. Safety assessment of dairy microorganisms: The Lactobacillus genus. International Journal of Food Microbiology 126: 278-285.

Bidarkar, V.K., Swain, P.S., Ray, S. \& Dominic, G. 2014. Probiotics: Potential alternative to antibiotics in ruminant feeding. Trends in Veterinary and Animal Sciences 1: 1-4.

Chiang, S.S. \& Pan, T.M. 2012. Beneficial effects of Lactobacillus paracasei subsp. paracasei NTU 101 and its fermented products. Applied Microbiology and Biotechnology 93(3): 903-916.

Chichlowski, M., Croom, W.J., Edens, F.W., McBride, B.W., Qiu, R., Chiang, C.C. \& Koci, M.D. 2007. Microarchitecture and spatial relationship between bacteria and ileal, cecal, and colonic epithelium in chicks fed a direct-fed microbial, PrimaLac, and salinomycin. Poultry Science 86(6): 11211132.

Choi, J.H., Lee, K., Kim, D.W., Kil, D.Y., Kim, G.B. \& Cha, C.J. 2018. Influence of dietary avilamycin on ileal and cecal microbiota in broiler chickens. Poultry Science 97(3): 970-979.

Conway, T. \& Cohen, P.S. 2015. Commensal and pathogenic Escherichia coli metabolism in the gut. Microbiology Spectrum 3(3): 1-24.

Dou, X., Gong, J., Han, X., Xu, M., Shen, H., Zhang, D. \& Zou, J. 2016. Characterization of avian pathogenic Escherichia coli isolated in Eastern China. Gene 576(1): 244-248.

Edens, F.W. 2003. An alternative for antibiotic use in poultry: Probiotics. Brazilian Journal of Poultry Science 5(2): 75-97.

Foster, J.W. 2004. Escherichia coli acid resistance: Tales of an amateur acidophile. Nature Reviews Microbiology 2(11): 898.

Fuller, R. 2001. The chicken gut microflora and probiotic supplements. The Journal of Poultry Science 38(3): 189196.

Gadde, U.D., Oh, S., Lillehoj, H.S. \& Lillehoj, E.P. 2018. Antibiotic growth promoters virginiamycin and bacitracin methylene disalicylate alter the chicken intestinal metabolome. Scientific Reports 8(1): 3592.

Getachew, T. 2016. A review on effects of probiotic supplementation in poultry performance and cholesterol levels of egg and meat. Journal of World's Poultry Research 6(1): 31-36

Hayirli, A., Esenbuğa, N., Macit, M., Yörük, M.A., Yıldız, A. \& Karaca, H. 2005. Nutrition practice to alleviate the adverse effects of stress on laying performance, metabolic profile and egg quality in peak producing hens: II. the probiotic supplementation. Asian-Australasian Journal of Animal Sciences 18(12): 1752-1760.

ISA. 2019. ISA Brown. Cage production systems, management report. https://www.isa-poultry.com/en/product/isa-brown/. Accessed on 27 March 2019. 
Khaksefidi, A. \& Ghoorchi, T. 2006. Effect of probiotic on performance and immunocompetence in broiler chicks. The Journal of Poultry Science 43(3): 296-300.

Landman, W.J.M. \& van Eck, J.H.H. 2017. The efficacy of inactivated Escherichia coli autogenous vaccines against the E. coli peritonitis syndrome in layers. Avian Pathology 46(6): 658-665.

Lokapirnasari, W.P., Pribadi, T.B., Al Arif, A., Soeharsono, S., Hidanah, S., Harijani, N., Najwan, R., Huda, K., Wardhani, H.C.P., Rahman, N.F.N. \& Yulianto, A.B. 2019a. Potency of probiotics Bifidobacterium spp. and Lactobacillus casei to improve growth performance and business analysis in organic laying hens. Veterinary World 12(6): 860-867.

Lokapirnasari, W.P., Al Arif, A., Soeharsono, S., Fathinah, A., Najwan, R., Wardhani, H.C.P., Noorrahman, N.F., Huda, K., Ulfah, N. \& Yulianto, A.B. 2019b. Improves in external and internal egg quality of Japanese quail (Coturnix coturnix japonica) by giving lactic acid bacteria as alternative antibiotic growth promoter. Iranian Journal of Microbiology 11(5): 406-411.

McGuckin, M.A., Lindén, S.K., Sutton, P. \& Florin, T.H. 2011. Mucin dynamics and enteric pathogens. Nature Reviews Microbiology 9(4): 265-278.

Mokszycki, M.E., Leatham-Jensen, M., Steffensen, J.L., Zhang, Y., Krogfelt, K.A., Caldwell, M.E., Conway, T. \& Cohen, P.S. 2018. A simple in vitro gut model for studying the interaction between Escherichia coli and the intestinal commensal microbiota in cecal mucus. Applied and Environmental Microbiology 84(24): e02166-18.

Møller, A.K., Leatham, M.P., Conway, T., Nuijten, P.J., de Haan, L.A., Krogfelt, K.A. \& Cohen, P.S. 2003. An Escherichia coli MG1655 lipopolysaccharide deep-rough core mutant grows and survives in mouse cecal mucus but fails to colonize the mouse large intestine. Infection and Immunity 71(4): 2142-2152.

Mookiah, S., Sieo, C.C., Ramasamy, K., Abdullah, N. \& Ho, Y.W. 2014. Effects of dietary prebiotics, probiotic and synbiotics on performance, caecal bacterial populations and caecal fermentation concentrations of broiler chickens. Journal of the Science of Food and Agriculture 94(2): 341-348.

Mountzouris, K.C., Tsitrsikos, P., Palamidi, I., Arvaniti, A., Mohnl, M., Schatzmayr, G. \& Fegeros, K. 2010. Effects of probiotic inclusion levels in broiler nutrition on growth performance, nutrient digestibility, plasma immunoglobulins, and cecal microflora composition. Poultry Science 89(1): 58-67.

Nayebpor, M., Farhomand, P. \& Hashemi, A. 2007. Effects of different levels of direct fed microbial (Primalac) on growth performance and humoral immune response in broiler chickens. Journal of Animal and Veterinary Advance 6(11): 1308-1313.

Niewold, T.A. 2007. The nonantibiotic anti-inflammatory effect of antimicrobial growth promoters, the real mode of action? A hypothesis. Poultry Science 86(4): 605-609.

Paixao, A.C., Ferreira, A.C., Fontes, M., Themudo, P., Albuquerque, T., Soares, M.C. \& Corrêa de Sá, M.I. 2016. Detection of virulence-associated genes in pathogenic and commensal avian Escherichia coli isolates. Poultry Science 95(7): 1646-1652.
Panda, A.K., Rama Rao, S.S., Raju, M.V. \& Sharma, S.S. 2008. Effect of probiotic (Lactobacillus sporogenes) feeding on egg production and quality, yolk cholesterol and humoral immune response of White Leghorn layer breeders. Journal of the Science of Food and Agriculture 88(1): 43-47.

Park, J.W., Jeong, J.S., Lee, S.I. \& Kim, I.H. 2016. Effect of dietary supplementation with a probiotic (Enterococcus faecium) on production performance, excreta microflora, ammonia emission, and nutrient utilization in ISA brown laying hens. Poultry Science 95(12): 2829-2835.

Paudel, S., Stessl, B., Hess, C., Zloch, A. \& Hess, M. 2016. High genetic diversity among extraintestinal Escherichia coli isolates in pullets and layers revealed by a longitudinal study. BMC Veterinary Research 12(1): 221.

Raka, P.S., Sjofjan, O. \& Radiati, L.E. 2014. Effect of liquid probiotics mixed culture supplements through drinking water on laying hens performance and yolk cholesterol. Journal of World's Poultry Research 4(1): 05-09.

Rattanawut, J., Pimpa, O. \& Yamauchi, K.E. 2018. Effects of dietary bamboo vinegar supplementation on performance, eggshell quality, ileal microflora composition, and intestinal villus morphology of laying hens in the late phase of production. Animal Science Journal 89(11): 1572-1580.

Shokryazdan, P., Sieo, C.C., Kalavathy, R., Liang, J.B., Alitheen, N.B., Faseleh Jahromi, M. \& Ho, Y.W. 2014. Probiotic potential of Lactobacillus strains with antimicrobial activity against some human pathogenic strains. BioMed Research International 2014: 927268.

Sohail, M.U., Rahman, Z.U., Ijaz, A., Yousaf, M.S., Ashraf, K., Yaqub, T. \& Rehman, H. 2011. Single or combined effects of mannan-oligosaccharides and probiotic supplements on the total oxidants, total antioxidants, enzymatic antioxidants, liver enzymes, and serum trace minerals in cyclic heatstressed broilers. Poultry Science 90(11): 2573-2577.

Srinu, B., Rao, T.M., Reddy, P.M. \& Reddy, K.K. 2013. Evaluation of different lactic acid bacterial strains for probiotic characteristics. Veterinary World 6(10): 785-788.

Tang, S.G.H., Sieo, C.C., Ramasamy, K., Saad, W.Z., Wong, H.K. \& Ho, Y.W. 2017. Performance, biochemical and haematological responses, and relative organ weights of laying hens fed diets supplemented with prebiotic, probiotic and synbiotic. BMC Veterinary Research 13(1): 248.

Untoo, M., Banday, M.T., Afzal, I., Adil, S., Baba, I.A. \& Khurshid, A. 2018. Potential of probiotics in poultry production. Journal of Entomology and Zoology Studies 6(3): 1293-1300.

Willis, W.L., Isikhuemhen, O.S. \& Ibrahim, S.A. 2007. Performance assessment of broiler chickens given mushroom extract alone or in combination with probiotics. Poultry Science 86(9): 1856-1860.

Yahfoufi, N., Mallet, J.F., Graham, E. \& Matar, C. 2018. Role of probiotics and prebiotics in immunomodulation. Current Opinion in Food Science 20: 82-91.

Yulianto, B. \& Lokapirnasari, W.P. 2018. Isolation and identification of lactic acid bacteria from the digestive tract of kampung chicken (Gallus gallus domesticus). The Philippine Journal of Veterinary Medicine 55(1): 67-72. 
Widya Paramita Lokapirnasari* \& Emy Koestanti Sabdoningrum Department of Animal Husbandry

Faculty of Veterinary Medicine

Universitas Airlangga

Jl. Mulyorejo, Kampus C, Surabaya, 60115

Indonesia

Adriana Monica Sahidu

Department of Marine

Faculty of Fisheries and Marine

Universitas Airlangga

Jl. Mulyorejo, Kampus C, Surabaya, 60115

Indonesia

\section{Lilik Maslachah}

Department of Basic Medicine

Veterinary Pharmacy Laboratory

Faculty of Veterinary Medicine

Universitas Airlangga

Jl. Mulyorejo, Kampus C, Surabaya, 60115

Indonesia
Andreas Berny Yulianto

Sains Veteriner

Faculty of Veterinary Medicine

Universitas Airlangga

Jl. Mulyorejo, Kampus C, Surabaya, 60115

Indonesia

*Corresponding author; email: widya-p-1@fkh.unair.ac.id

Received: 6 April 2019

Accepted: 14 February 2020 